\title{
Estimation of Rice Losses while Harvesting the Crop by Manual Method and by Using Propeller Type Small Combine Harvester
}

\author{
K.T. Ramappa ${ }^{1 *}$, H. Sharanagouda ${ }^{1}$, R. Udhayakumar ${ }^{2}$ and D.S.K. Devadattam ${ }^{1}$ \\ ${ }^{1}$ Department of Processing and Food Engineering, CAE, UAS, Raichur, India \\ ${ }^{2}$ Faculty of Agriculture and Animal Husbandry, GRI, Dindigul, India \\ *Corresponding author
}

\begin{tabular}{|l|}
\hline Ke y w o r d s \\
Rice, Conventional \\
harvesting, Self \\
propelled combine \\
harvester, Field \\
capacity
\end{tabular}

A B S T R A C T

Rice is one of the main crops in Raichur district of Karnataka. During harvesting season, shortage of labour demands suitable machinery in this region. Field evaluation trials of self-propelled type small combine harvester for harvesting of rice crop were carried out and the results were compared with manual rice harvesting method. Studies on conventional method of rice harvesting revealed that, the average field capacity of conventional method was 0.009 hectare per hour and the average total grain loss was found to be 11.16 per cent. The cost of harvesting worked out for conventional method was ₹ 9,264.00 per hectare. However, the experiment conducted for small rice combine harvester revealed that the average field capacity and field efficiency were $0.123 \mathrm{ha} / \mathrm{h}$ and 90.25 per cent, respectively. The grin losses occurred with the machine was observed to be 5.43 per cent. The cost of operation was worked out to be ₹ $4,543.00$ per hectare.

\section{Introduction}

India is the seventh largest country in the world by area, with 329 Mha. The net area sown is nearly 142 Mha, of which only 39 per cent is irrigated, while the gross cropped area is approximately 189 Mha (Tiwari, 2002).

Out of 189 Mha of cropped area, rice occupies an area of 42.86 Mha with a production of 95.98 MT (India Stat, 2010-11). Rice continues to hold the key to sustain food security in the country, so even if rice production areas stabilize or register negative growth, future rice production targets must be achieved exclusively through yield improvement and reducing post-harvest losses by optimum mechanization. There was a considerable increase in rice production in the last two decades, but due to lack of knowledge of improved post-harvest technology (i.e., harvesting, threshing, drying and storage) a sizable portion of the produce was lost either in the field or in storage (Manjit Singh, 1998). 
In rice cultivation, transplanting, harvesting and threshing are the three major labour intensive operations. Harvesting and threshing are the most important operations in the entire range of field operations, which are laborious involving human drudgery and requires about 150-200 man-h/ha for harvesting of rice alone (Veeranagouda et al., 2010). Traditionally, rice is harvested manually by using sickles. Due to the non-availability of labourers, crop harvesting is often delayed which exposes the crop to vagaries of nature. Timely harvesting is at most important, as delayed harvesting leads to a considerable loss of grain and straw owing to over maturity resulting in loss of grains by shattering and also hampers the seed bed preparation and sowing operations for the next crop. The paucity of labour force is forcing the farmers to go for other crops, which are more remunerative and less labour intensive, thus affecting the rice production.

The manual harvesting using sickles need 180 and $200 \mathrm{man} \mathrm{h} / \mathrm{ha}$ to harvest rice and wheat, respectively (Pande and Devnani, 1984). However, mechanical harvesting can overcome this constraint. The Holland European self-propelled all crop combine harvester was having the average field capacity of $1.05 \mathrm{ha} / \mathrm{h}$ with an average field efficiency of 72 per cent, and the machine losses over grain was 1.68 per cent of the total grain yield which were reasonable.

Although the trailed combines have been made and introduced in 1935, and selfpropelled combines appeared commercially in about 1939 in USA. These combines were used mainly on dry land for wheat harvesting. Some self-propelled combines might be used in USA to harvest rice crop in dry land condition. But they are not suitable to harvest the rice crop in wet field condition. The yield of rice crop and straw would be double compared to wheat, and the machine has to harvest rice crop not only in wet condition but also to handle double quantities of material so that the systems and running parts of the rice harvester should be considered and designed to meet the needs of the farmers (Kanuengsak, 2009).

The self-propelled combine harvester will help to harvest the crop in time, so that the land can be prepared for next crop. The cost of machine harvesting is found less than the manual operation (Kalsirisilp and Gajendra, 1999). The saving of grains is more, because of elimination of losses of grains at various phases. Not only these machines save time but also ensure quality and more yield.

Although, there has been numerous studies regarding the effect of harvesting and threshing methods on rice losses but limited research has taken place to compare direct harvesting through small rice combine harvesters with indirect harvesting namely manual harvesting and or reaper plus threshing. Therefore, this study aimed to investigate grain losses by considering the technical and field aspects of utilizing small rice combine harvesters and comparing them with manual harvesting on the view of quantitative and qualitative grain losses.

\section{Materials and Methods}

Raichur is the Northern state of Karnataka, located at $16.12^{\circ} \mathrm{N}$ latitude, $16.24^{\circ} \mathrm{E}$ longitude and is $389.5 \mathrm{~m}$ above mean sea level. The study area was selected because the area under rice cultivation was high $(1,76,440$ ha), when compared to other parts of the state and is known as the rice bowl of Karnataka. In this district, two taluks viz., Sindhanur and Manvi were selected for conducting field experiments. The two taluks stood first and second in area wise rice cultivation i.e., 92,020 ha and 60,499 ha, respectively (District Statistics, 2009-10). In Sindhanur and Manvi taluks, normally the IR-64 rice variety is 
cultivated during kharif season (April) and Sona masuri is the dominant crop variety during rabi season (December). The study area chosen was rural, where the majority of the farmers had small land holdings.

During field study, observation plots were selected randomly in the field for recording observations of post-harvest grain losses of rice that occur during conventional and small rice combine harvester methods of harvesting for two seasons in two taluks of Raichur district in the year 2009-10.

\section{Conventional rice harvesting system}

Manual harvesting of rice crop was carried out with the help of different sickles by cutting the plants 10 to $30 \mathrm{~cm}$ above the ground level. After cutting, the rice stalks were left on the ground for drying for one or two days. Then, the dried stalks were tied by a single rice stalk to form a bundle. The size of each bundle depends upon the choice of the harvester or farmer. Bundles are then gathered at one spot for transportation to the threshing yard mainly by head/shoulder or by animal pulled carts depending upon land situation, area of threshing, capability of farmer and situation exists in the field. Threshing of crop was done mainly by tractor treading method by hiring a tractor. Due to movement of tractor wheels on the crop mass, the grains threshed from the panicle. Finally the threshed grains were separated from straw and chaffy materials by winnowing. Winnowing was done by using wind speed for cleaning or separating the grain from straw and husk.

\section{Field test parameters}

Pre harvest parameters considered during field survey were: area of field, crop variety, plant height, mode of planting, grain moisture content, grain-straw ratio, type of soil and soil moisture content. During crop harvesting the following parameters were considered: pre harvest loss, cutting loss, drying loss, bundling loss, conveying loss, threshing loss, winnowing loss, time taken for harvesting, bundling, conveying, threshing, winnowing and cost of operation. The procedure used for recording the above said parameters are described below.

In each randomly selected field before the harvest, grain yield in one square meter area was estimated. Three observations were taken randomly to arrive at the average grain yield. This value was kept for estimating the other post-harvest losses. The pre-harvest losses were those grains that fell on the ground due to wind and other factors not related to harvesting process/machine use. The grains that had fallen in the measured area were weighed and expressed in percentage basis (FMO, 1987).

For every harvesting operation such as cutting, bundling, conveying, threshing and winnowing, weight of grain was observed before and after completing the operation and expressed in per cent. In case of drying loss, the grains fallen on the ground after drying operation in the measured area before bundling was measured and expressed in per cent.

Five samples of grain (10 g per sample) and straw (100 g per sample) were collected in the test field randomly at the time of harvest for observing the moisture content. It was determined by keeping the samples in a hot air oven at a temperature of $105^{\circ} \mathrm{C}$ for twenty four hours. The same procedure was adopted for finding the soil moisture content also. The moisture content of both was expressed in percentage wet basis. A stopwatch was used to record the time involved in completing the operations like harvesting, bundling, conveying, threshing and winnowing in the test field conditions. 
The cost of post-harvest operations in conventional system was calculated by taking the actual number of labourers employed for completing each operations and the average wage paid per labour.

\section{Small rice combine harvester}

The small rice combine harvester is a kind of multi-functional rice harvesting machine, especially suits for all kinds of areas like plane, hills and mountains or areas where general combined harvesters cannot enter in, very convenience for the farming. The selfpropelled small rice combine harvester which was available in College of Agricultural Engineering, Raichur, was selected for the study. The details of the subsystems of small rice combine harvester are furnished in Table 1 and the pictorial view of a small combine is shown in Plate 1.

Estimation of grain loss in small rice combine harvester

The following parameters were considered for finding the field performance evaluation of small rice combine harvester.

\section{Pre harvest loss}

The procedure followed for determination of estimated grain yield and pre harvest losses are similar to that of conventional method. The procedure was adopted by referring FMO (1987) to determine all the other post-harvest losses.

\section{Machine operational parameters}

The operational parameters were recorded when the machine was operating in the same field, same season and same soil conditions which were considered for manual method of harvesting. The parameters included were forward speed of the machine, effective working width, cutting height and time taken to cover the area. Based on these observations field capacity and field efficiency of the machine were computed.

Speed of operation was determined by recording the time taken by the machine to travel a predetermined distance in the field, which varied from 10 to 30 meters depending upon the field length. The average of five observations was considered as mean to calculate the speed of operation. The total working width for five consecutive runs was recorded in the field test. The average of five such observations was considered as the effective working width of the small rice combine harvester.

The effective field capacity and field efficiency were determined by counting all the time components involved in the harvesting operation. The total time was categorized into productive and non-productive times. The productive time is the actual time used for harvesting the grains. The non-productive time consists of the time required for turning, repair, adjustment and unloading of grains. These time elements were measured with the help of a stop watch in each tested field. The area covered divided by the total time gives the effective field capacity. For computing the effective field capacity the following formula was used.

A

$\mathrm{EFC}=\mathbf{- - - - - - - - - - - - - - - -}$

Where, $\mathrm{EFC}=$ Effective field capacity, ha/h

$\mathrm{A}=$ Area covered, ha

$\mathrm{Tp}=$ Productive time, $\min$.

$\mathrm{Tn}=$ Non-productive time (turning time, repair and adjustment time, other time losses, min. 
Field Efficiency, $\mathrm{E}_{\mathrm{f}}=\{($ Productive time $) /$ (Total time) $\} \times 100$

\section{Small combine harvester subsystem parameters}

The total grain losses are the sum of the preharvest losses, header/cutter bar losses, threshing/cylinder losses, and separator/ shoe losses. The machine operation losses refer to the summation of header/cutter bar loss, threshing/cylinder loss and shoe/separator loss (FMO, 1987; Hunt, 1995). The methods determining the various losses are as discussed below.

\section{Cutter bar loss}

The cutter bar loss is caused by faulty adjustment and operation of cutting platform (FMO, 1987). In order to determine the cutter bar/ header losses, the frame $(1 \mathrm{~m} \times 1 \mathrm{~m})$ was placed on the ground in front of the combine within the harvested area after backing the length of the machine. Grains found inside the frame were collected and counted. Similarly, grains were also collected from other two places of the studied plot. Grains found from three places were averaged and pre-harvest loss checked was subtracted to calculate the cutter bar loss.

Cutter bar loss, CL $(\%)=\left(\mathrm{Wcl} / \mathrm{Y}_{\mathrm{E}}\right) \times 100$

Where, $\mathrm{Wcl}=$ Weight of cutter bar loss, $\mathrm{kg} / \mathrm{ha}$ $\mathrm{Y}_{\mathrm{E}}=$ Estimated grain yield of crop, $\mathrm{kg} / \mathrm{ha}$

\section{Threshing loss}

The threshing loss was calculated by collecting 100 gram sample from main outlet and weighed. Grains are separated from unthreshed including the damaged ones. Five such samples are collected from grain outlet and the average of threshing loss is expressed in percentage basis.
Threshing loss, ThL $(\%)=\left(\mathrm{Wthl} / \mathrm{Y}_{\mathrm{E}}\right) \times 100$

Where, Wthl = Weight of threshed grains, $\mathrm{g}$

$\mathrm{Y}_{\mathrm{E}}=$ Total grain sample, $\mathrm{g}$

\section{Separation loss}

The separation loss is caused by more material flow over walker, chaffer, higher air velocity from blower and improper adjustment of chaffer and sieve (FMO, 1987). In determination of separator or shoe losses, the square frame (1m x 1m) was placed on ground directly behind the separator or machine discharge. A sickle was used to cut the straws and plant stubbles found inside the square bar which was removed. The threshed grains lying on the ground were then collected later.

Similarly, three samples were collected randomly and were averaged to the number of threshed grains. Grain found in the header-loss and pre-harvest loss was then subtracted from the averaged collected grains. The remaining value was given as number of grain loss over the separator or shoe.

Separation loss, SL $(\%)=\left(\right.$ Wuthg $\left./ \mathrm{Y}_{\mathrm{E}}\right) \times 100$

Where, Wuthg = Weight of unthreshed grain, $\mathrm{g}$

$\mathrm{Y}_{\mathrm{E}}=$ Total sample weight, $\mathrm{g}$

\section{Cost economics of rice combine harvester}

The cost of harvesting with manual method and using small rice combine harvester was calculated by considering standard procedure and is given in Table 2 and 3. The fixed and variable costs were used to calculate the total cost of the machine operation per hour. The total operational cost of machine per hectare was calculated by dividing the same by effective field capacity. 


\section{Results and Discussion}

\section{Estimation of grain losses in conventional harvesting system}

Studies were conducted to assess the amount of grain losses in manual harvesting system. Field observations like time taken to harvest the crop and field capacity of conventional harvesting system for both first and second cropping seasons in farmers' fields at Sindhanur and Manvi taluks were recorded and the values are presented in Table 4.

The values presented in Table 4. gives the average data of experiments conducted in twelve different fields of Sindhanur and Manvi taluks for the two crop seasons (Kharif and Rabi) and for 2 varieties of rice (Sona masoori and IR-64). In the table it was found that, the field capacity of conventional method varied from 0.008 to $0.011 \mathrm{ha} / \mathrm{h}$ with an average field capacity of 0.009 hectare per hour. The total grain losses found ranged from 10.94 to 11.44 per cent with an average loss of 11.16 per cent. The moisture content of grain was found in the range of 23.05 to 23.20 per cent.

While comparing results, which represented two taluks for two crop seasons, it revealed that the variation in field capacity between the taluks could be due to difference in land location with respect to threshing area, difference in climatic conditions at the time of harvest and varied experience of engaged labourers for attending different field operations.

In the table, it was observed that for grain losses, percentage of losses were found to be higher in threshing operation followed by losses due to cutting, bundling, conveying, winnowing and drying irrespective of season, variety and location. It could be due to adoption of tractor treading on the irregular floor for threshing to separate grains from ear heads which caused more losses in the form of unthreshed grain, broken grains and disappearing of grain in to the soil. Use of unserrated country sickles for harvesting results more shattering, transportation of harvested produce by head load which cause jerking action, winnowing operation done in the elevated position against natural wind were some of the lengthy, labourious and uncontrolled conventional operations attributed towards grain losses.

Further from the results it was noticed that the threshing required more time when compared to other operations irrespective of season, variety and location. It could be due to the use of conventional methods, which have no direct control over grain to create required abrasion for separation of grain from panicle. It also again depended upon weather conditions, availability of skilled labour and space required to carry out threshing in time.

The cost of operations involved in the conventional rice harvesting system and other post harvesting operations of rice were calculated by taking the number of labourers engaged for each operation and wages given in Table 2. The total cost for conventional harvesting of rice was found to be ₹ 2062.50 per hectare. The costs of operations depend mainly on the crop condition and the availability of labour during harvesting time.

The cost of bundling and transporting of harvested material to threshing yard was arrived at $₹ 1500.00$ per hectare. The cost of tractor treading for threshing and the cost of labour for winnowing were ₹ 637.50 and ₹ 600.00 per hectare, respectively. From the field experiments an average field capacity of 0.009 hectare per hour with an average loss of 11.16 per cent was observed. The cost of grain losses was calculated by considering the regional market price of grain i.e., ₹ 8.00 per 
kilogram and it was worked out to be ₹ 4464.00 per hectare. Thus the total cost of harvesting of rice by conventional system, which included harvesting, bundling, transportation, threshing, winnowing and the expected loss of threshing worked out was ₹ 9,264.00 per hectare. Higher cost of operation in conventional harvesting attributed to the less field capacity by using more man-hour per hectare labour and higher grain losses.

\section{Estimation of grain losses during harvesting using small combine harvester}

The rice harvesting operations carried out by small combine harvester for harvesting of rice and the operations were monitored in two taluks and data were collected for two seasons for two varieties of rice i.e., Sona masoori and IR-64. The performance data of small rice combine harvester is presented in Table 5
The small rice harvester was tested in 12 fields for two seasons in two taluks for two varieties of rice and the field parameters were observed and the average values are presented in table 5 . The moisture content of grain was found in the range of 18.21 to 18.30 per cent at the time of harvest. The effective field capacity of the small rice combine machine varied from 0.121 to 0.125 hectare per hour with an average of 0.123 hectare per hour. The field efficiency of the machine varied from 89.41 to 91.28 per cent with an average field efficiency of 90.25 per cent. The total grain losses varied from 5.35 to 5.48 per cent with an average of 5.44 per cent. The pre harvest losses varied from 0.34 to 0.41 per cent with an average of 0.38 per cent. The average cutter bar and threshing loss were found to be 0.59 and 2.16 per cent, respectively. The separation losses varied from 2.30 to 2.33 per cent with an average of 2.32 per cent.

Plate.1 Pictorial view of a small combine harvester

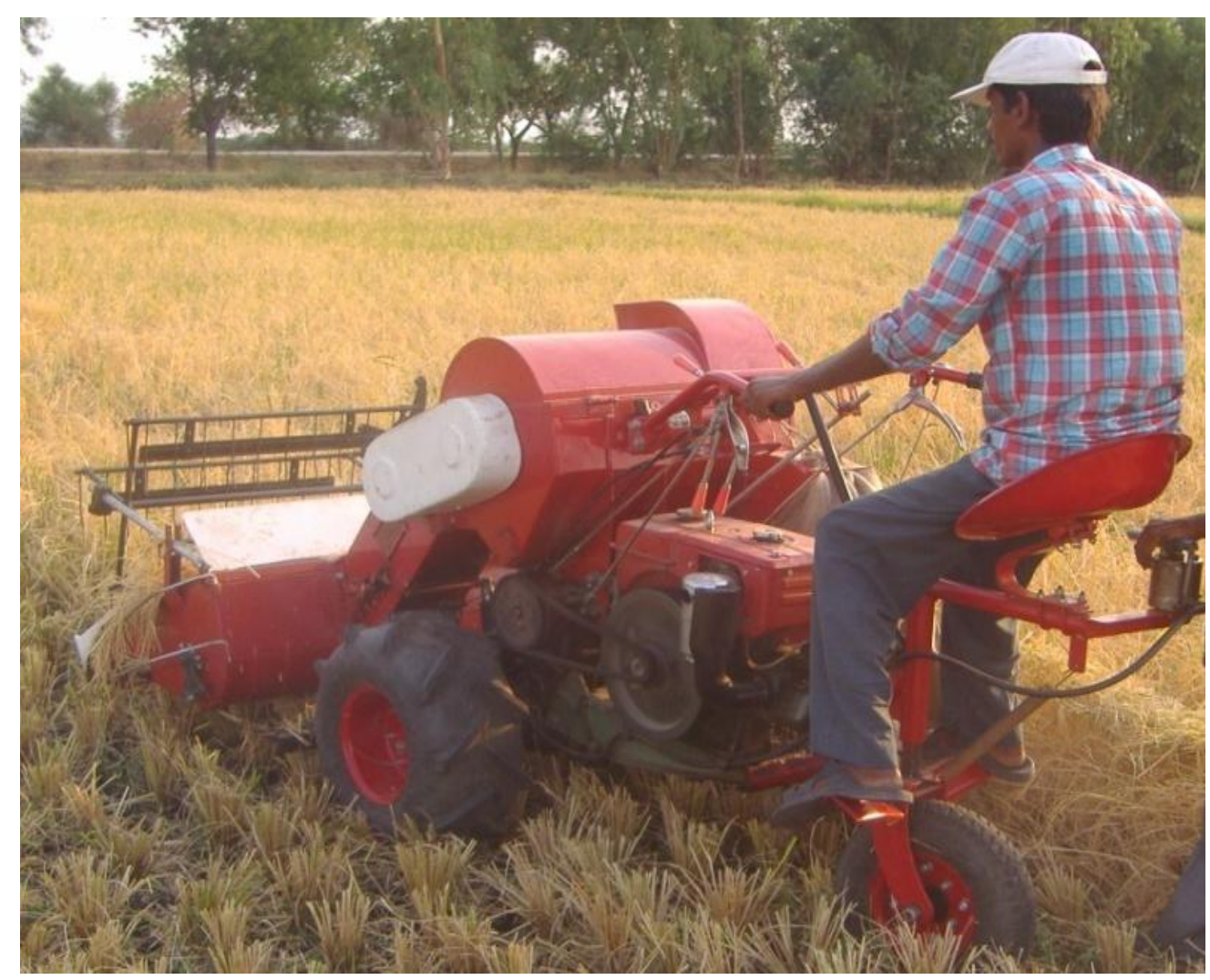


Table.1 Specifications of small rice combine harvester

\begin{tabular}{|c|c|c|}
\hline Sl. No. & Sub System & Specifications \\
\hline \multirow[t]{2}{*}{1} & \multirow[t]{2}{*}{$\begin{array}{l}\text { Engine and } \\
\text { propulsion system }\end{array}$} & $\begin{array}{l}\text { Power - } 8.38 \mathrm{hp} \\
\text { Rated Engine speed - } 1800 \mathrm{rpm}\end{array}$ \\
\hline & & $\begin{array}{l}\text { Clutch- Belt driven dry type multi plate clutch } \\
\text { Transmission- } 4 \text { forward \& } 1 \text { reverse } \\
\text { PTO speed - } 225 \mathrm{rpm} \\
\text { Type- Riding type with tail wheel } \\
\text { Engine mounting- rear mounted }\end{array}$ \\
\hline 2 & Harvesting system & $\begin{array}{l}\text { Type - Reciprocating cutter bar } \\
\text { Length of cutter bar- } 0.9 \mathrm{~m} \\
\text { Conveyor type- platform auger } \\
\text { Crop lifting mechanism- by reel mechanism }\end{array}$ \\
\hline 3 & $\begin{array}{l}\text { Threshing and winnowing } \\
\text { system }\end{array}$ & $\begin{array}{l}\text { Type - axial flow } \\
\text { Length of drum }-690 \mathrm{~mm} \\
\text { Diameter of drum }-474 \mathrm{~mm} \\
\text { Concave - interchangeable- wire mesh type or } \\
\text { perforated sheet type. } \\
\text { Grain collection- cross flow auger } \\
\text { Grain discharge- Flipper vanes on auger shaft }\end{array}$ \\
\hline 4 & Conveyor & Belt type conveyor with metal slates \\
\hline 5 & $\begin{array}{l}\text { Tail wheel and seating } \\
\text { arrangement }\end{array}$ & Adjustable height of operator's seat \\
\hline \multicolumn{3}{|c|}{ Power transmission system } \\
\hline 1 & Main clutch & Multi plate dry type \\
\hline 2 & Gear box & 4 forward / 1 Reverse \\
\hline 3 & Turning clutch & Dog clutch on gears \\
\hline 4 & Over all Dimensions & $1675 \times 530 \times 220 \mathrm{~mm}$ \\
\hline 5 & Weight & $450 \mathrm{~kg}$ \\
\hline
\end{tabular}

Table.2 Cost of operation of conventional harvesting system

\begin{tabular}{|c|c|c|c|c|c|}
\hline $\begin{array}{l}\text { Sl. } \\
\text { No }\end{array}$ & Parameters & $\begin{array}{l}\text { Working } \\
\text { hours }\end{array}$ & $\begin{array}{l}\text { Rate } \\
\text { (₹/h) }\end{array}$ & $\begin{array}{l}\text { Amount } \\
\text { (₹/ha) }\end{array}$ & $\begin{array}{l}\text { Percent of } \\
\text { utilization }\end{array}$ \\
\hline 1 & Manual harvesting & $110 \mathrm{man}-\mathrm{h} / \mathrm{ha}$ & 18.75 & 2062.50 & 43.00 \\
\hline 2 & $\begin{array}{l}\text { Bundling and } \\
\text { conveying }\end{array}$ & $80 \mathrm{man}-\mathrm{h} / \mathrm{ha}$ & 18.75 & 1500.00 & 32.00 \\
\hline 3 & $\begin{array}{l}\text { Threshing by tractor } \\
\text { treading }\end{array}$ & $34 \mathrm{man}-\mathrm{h} / \mathrm{ha}$ & 18.75 & 637.50 & 13.00 \\
\hline 4 & Winnowing & $32 \mathrm{man}-\mathrm{h} / \mathrm{ha}$ & 18.75 & 600.00 & 12.00 \\
\hline 5 & \multicolumn{3}{|c|}{ Cost of harvesting operation $(1+2+3+4)$} & 4800.00 & 100.00 \\
\hline \multirow[t]{2}{*}{6} & \multicolumn{3}{|c|}{$\begin{array}{l}\text { Considering } \\
\text { Grain loss - } 11.16 \text { per cent } \\
\text { Estimated yield }-5.00 \text { tonnes per hectare } \\
\text { Cost of grain }-₹ 8.00 \text { per kilogram }\end{array}$} & 4464.00 & \\
\hline & \multicolumn{3}{|c|}{ Total cost } & 9264.00 & - \\
\hline
\end{tabular}


Table. 3 Cost of operation of small rice combine harvester

\begin{tabular}{|c|c|c|}
\hline Particulars & Unit & Amount \\
\hline 1. Machine cost & ₹ & $2,50,000.00$ \\
\hline 2. Yearly use & $\mathrm{H}$ & $\mathbf{5 0 0 . 0 0}$ \\
\hline 3. Useful life & Years & 10.00 \\
\hline 4. Salvage value ( $10 \%$ machine cost) & $₹$ & $25,000.00$ \\
\hline \multicolumn{3}{|l|}{ 5. Fixed costs per hour } \\
\hline a. Depreciation & ₹/h & 45.00 \\
\hline b. Interest (@ 11.5 / year) & $₹ / \mathrm{h}$ & 25.87 \\
\hline Total fixed cost $(₹ / h)$ & $₹ / \mathrm{h}$ & $\mathbf{7 0 . 8 7}$ \\
\hline \multicolumn{3}{|l|}{ 6. Variable cost per hour } \\
\hline a. Fuel cost (@ 56.00 (1.5 lit/h) & ₹/h & 84.00 \\
\hline b. Lubricant cost ( $30 \%$ of fuel cost) & $₹ / \mathrm{h}$ & 25.20 \\
\hline \multicolumn{3}{|l|}{ c. Labour cost } \\
\hline i) One operator (@ Rs. 250 (per operator) & ₹/h & 31.25 \\
\hline $\begin{array}{l}\text { d. Repair and maintenance ( } 5 \% \text { of Machine cost } \\
\text { per year) }\end{array}$ & ₹/h & 25.00 \\
\hline Total variable cost & $₹ / \mathrm{h}$ & 165.45 \\
\hline 7. Total machine cost $(5+6)$ & $₹ / \mathrm{h}$ & 236.32 \\
\hline 8. Average field capacity of the machine & ha/h & 0.123 \\
\hline 9. Variable cost of operation (6/8) & ₹/ ha & 1345.12 \\
\hline 10. Operation cost of the machine $(7 / 8)$ & ₹/ ha & 1921.30 \\
\hline $\begin{array}{l}\text { 11. Average cost for clearing the headlands } \\
\text { Labour required - } 16 \text { man-hour } \\
\text { Labour rate - Rs. } 150.0 \text { per day of } 8 \text { hour }\end{array}$ & ₹/ ha & 300.00 \\
\hline $\begin{array}{l}\text { 12. Considering } \\
\text { Grain loss }-5.43 \text { per cent } \\
\text { Estimated yield }-5.0 \text { tonnes per hectare } \\
\text { Cost of grain - Rs. } 8.00 \text { per kilogram }\end{array}$ & ₹/ ha & 2172.00 \\
\hline $\begin{array}{l}\text { 12. Total cost of harvesting with machine } \\
\text { operation was }(10+11+12)\end{array}$ & ₹/ ha & 4393.00 \\
\hline Rounded off & & 4393.00 \\
\hline Transporting charges & ₹/ha & 150.00 \\
\hline Total cost & ₹/ha & 4543.00 \\
\hline
\end{tabular}


Table.4 Field evaluation of conventional rice harvesting system conducted for two crop varieties during two cropping season in two taluks of Raichur

\begin{tabular}{|c|c|c|c|c|c|c|c|c|c|c|c|c|}
\hline $\begin{array}{l}\text { Name of } \\
\text { the taluk }\end{array}$ & $\begin{array}{l}\text { Name of } \\
\text { the variety }\end{array}$ & $\begin{array}{l}\text { Croppi } \\
\text { ng } \\
\text { season }\end{array}$ & $\begin{array}{c}\text { M.C of } \\
\text { grain, } \\
(\%)\end{array}$ & $\begin{array}{c}\text { Field } \\
\text { capacit } \\
\text { y, } \\
(\mathbf{h a} / \mathbf{h})\end{array}$ & $\begin{array}{c}\text { Pre } \\
\text { harvest } \\
\text { loss, } \\
(\%)\end{array}$ & $\begin{array}{c}\text { Cutting } \\
\text { loss, } \\
(\%)\end{array}$ & $\begin{array}{l}\text { Dryin } \\
\text { g } \\
\text { losses, } \\
(\%)\end{array}$ & $\begin{array}{c}\text { Bundling } \\
\text { losses, } \\
(\%)\end{array}$ & $\begin{array}{l}\text { Conveying } \\
\text { losses, } \\
(\%)\end{array}$ & $\begin{array}{c}\text { Threshing } \\
\text { losses, } \\
(\%)\end{array}$ & $\begin{array}{l}\text { Winnowing } \\
\text { losses, } \\
(\%)\end{array}$ & $\begin{array}{c}\text { Total } \\
\text { losses, } \\
(\%)\end{array}$ \\
\hline Sindhanur & \multirow[t]{2}{*}{ IR-64 } & \multirow[t]{2}{*}{ Kharif } & 23.05 & 0.008 & 0.28 & 1.66 & 0.52 & 1.60 & 1.01 & 5.04 & 0.90 & 11.01 \\
\hline Manvi & & & 23.06 & 0.011 & 0.44 & 1.48 & 0.50 & 1.31 & 1.41 & 5.14 & 1.17 & 11.44 \\
\hline Sindhanur & \multirow{2}{*}{$\begin{array}{l}\text { Sona } \\
\text { masuri }\end{array}$} & \multirow[t]{2}{*}{ Rabi } & 23.18 & 0.009 & 0.28 & 1.79 & 0.60 & 1.60 & 1.27 & 4.49 & 1.21 & 11.24 \\
\hline Manvi & & & 23.20 & 0.009 & 0.33 & 1.58 & 0.63 & 1.32 & 1.52 & 4.40 & 1.15 & 10.94 \\
\hline \multicolumn{3}{|c|}{ Average } & 23.12 & 0.009 & 0.33 & 1.63 & 0.56 & 1.46 & 1.30 & 4.77 & 1.11 & 11.16 \\
\hline
\end{tabular}

Table.5 Field evaluation of small rice combine harvester conducted in two taluks of Raichur district for two crop varieties during two crop seasons

\begin{tabular}{|c|c|c|c|c|c|c|c|c|c|c|}
\hline Name of taluk & $\begin{array}{l}\text { Name of } \\
\text { the variety }\end{array}$ & $\begin{array}{l}\text { Cropping } \\
\text { season }\end{array}$ & $\begin{array}{c}\text { M.C of } \\
\text { grain, } \\
(\%)\end{array}$ & $\begin{array}{l}\text { Effective } \\
\text { field } \\
\text { capacity, } \\
\text { (ha/h) }\end{array}$ & $\begin{array}{c}\text { Field } \\
\text { efficienc } \\
\mathbf{y},(\%)\end{array}$ & $\begin{array}{c}\text { Pre } \\
\text { harvest } \\
\text { loss, }(\%)\end{array}$ & $\begin{array}{c}\text { Cutter } \\
\text { bar loss, } \\
(\%)\end{array}$ & $\begin{array}{c}\text { Threshin } \\
\text { g loss, } \\
(\%)\end{array}$ & $\begin{array}{c}\text { Separation } \\
\text { loss, } \\
(\%)\end{array}$ & $\begin{array}{c}\text { Total loss, } \\
(\%)\end{array}$ \\
\hline Sindhanur & \multirow[t]{2}{*}{ IR-64 } & \multirow[t]{2}{*}{ Kharif } & 18.25 & 0.124 & 91.28 & 0.34 & 0.58 & 2.13 & 2.30 & 5.35 \\
\hline Manvi & & & 18.23 & 0.121 & 90.00 & 0.37 & 0.60 & 2.17 & 2.33 & 5.47 \\
\hline Sindhanur & \multirow{2}{*}{$\begin{array}{c}\text { Sona } \\
\text { masuri }\end{array}$} & \multirow[t]{2}{*}{ Rabi } & 18.21 & 0.125 & 90.29 & 0.38 & 0.59 & 2.15 & 2.32 & 5.44 \\
\hline Manvi & & & 18.30 & 0.123 & 89.41 & 0.41 & 0.58 & 2.17 & 2.32 & 5.48 \\
\hline \multicolumn{3}{|c|}{ Average } & 18.25 & 0.123 & 90.25 & 0.38 & 0.59 & 2.16 & 2.32 & 5.44 \\
\hline
\end{tabular}


In both the taluks, among the total grain loss, losses observed in separation was found high followed by thresher loss, cutter bar loss and pre-harvest loss irrespective of season, variety and operators' skill. The occurrence of higher separation losses was due to the choking of straw in the threshing unit and not exposing completely for threshing operation. This could also be the main reason for higher threshing loss as well.

The variations in the field efficiency might be due to machine operator's skill. Besides operators' skill, the variations in the field capacities might also due to the field size, ground and crop conditions, which affected the forward speed of the machine. The field capacity and field efficiency also affected by the time spent for turning, unloading of grain, repair of machine and other adjustments.

\section{Cost of operation of small rice combine harvester}

The cost of operations involved in small rice combine harvester is given in Table 3 the average field capacity of the machine was taken as 0.123 hectare per hour. The total cost of harvesting was found to be ₹ 1921.30 per hectare by taking into account the fixed cost and variable cost of the machine. However, for arriving at the actual cost of harvesting two more components to be added. One is the clearing cost of headlands for accommodating the machine in the field and another is the cost of grain loss. From the field observations, the actual labours involved in clearing the headlands were taken for calculation. The estimated grain yield and grain losses were taken as 5.0 tonnes per hectare and 5.44 per cent, respectively. These values arrived by taking the averages of respective field data observed in two taluks for two seasons. Regional market price of grain as $₹ 8.00$ per kilogram was taken for calculation of cost of grain loss, which was worked out ₹ 2172.00 per hectare. The total cost of operation by using combine harvester was worked out to be ₹ 4393.00 per hectare. In addition to this, it was observed that normally the contractor claim ₹ 150.00 per hectare for the transportation charges. Thus for the farmer, the total operational cost worked out to be ₹ 4543.00 per hectare.

\section{Comparison of rice combine harvester with conventional harvesting system}

For comparison between small rice combine harvester and conventional harvesting system, the parameters considered were time required for harvesting ( $\mathrm{min})$, total grain losses (\%) and cost of operation ( ₹/ha). The total time required for completing harvesting and threshing operations in conventional harvesting method was $6350.51 \mathrm{~min}$, whereas in the small rice combine harvester it was $487.8 \mathrm{~min}$. The total grain losses were found to be more in conventional method of harvesting (11.16 per cent) as compared to small rice combine harvester (5.44 per cent). The cost of operation in conventional method was 2.04 times more than that of small rice combine harvester. Hence, small rice combine harvester is found efficient and economic for rice harvesting when compared to the conventional harvesting system in the study area irrespective of season and location.

Studies on conventional method of rice harvesting depicted that, the rice was harvested at an average grain moisture content of 23.12 per cent and the field capacity varied from 0.008 to 0.011 hectare per hour with an average field capacity of 0.009 hectare per hour. The total grain losses ranged between 10.94 to 11.44 per cent with an average loss of 11.16 per cent. The total cost of harvesting of rice by conventional system, which included harvesting, bundling, transportation, threshing, winnowing and the expected loss of threshing was worked out to 
be ₹ 9,264.00 per hectare. More grain loss in conventional method of rice harvesting attributed to the various lengthy, labourious and uncontrolled conventional operations such as cutting, bundling, conveying, winnowing and drying. Percentage of loss was found to be higher in threshing operation followed by cutting, bundling, conveying, winnowing and drying operations irrespective of season, variety and location.

Studies on small rice combine harvester which was used for harvesting two crops for two seasons in two taluks revealed that the harvesting operation was carried out at an average moisture content of 18.25 per cent. The average field capacity of small rice combine was found to be $0.123 \mathrm{ha} / \mathrm{h}$ and the average field efficiency recorded was 90.25 per cent. The major losses occurred with the machine were cutter bar loss, threshing loss and separation loss. The average values recorded with respect to above losses were $0.59,2.16$ and 2.32 per cent, respectively totaling 5.44 per cent.

Comparison of small rice combine harvester with conventional harvesting system revealed that the time required for harvesting and threshing operations in conventional harvesting method was $6350.51 \mathrm{~min}$, whereas in the small rice combine harvester it was $487.8 \mathrm{~min}$. The total grain losses were found to be more in conventional method of harvesting (11.16 per cent) as compared to small rice combine harvester (5.44 per cent). The cost of operation in conventional method was 2.04 times more than that of small rice combine harvester. Hence, small rice combine harvester is found efficient and economic for rice harvesting when compared to the conventional harvesting system in the study area irrespective of season and location.

\section{References}

FMO, 1987. Combine harvesting, Fundaments of machine operation, $3^{\text {rd }}$ edition Deere and company service training, Moline, Illinois, U.S.A.

Kalsirisilp and Gajendra Singh, 1999. Performance evaluation of Thai-made rice combine harvester, AMA, Vol. 30(4), 63-69.

Kanuengsak Chiaranaikul, 2009. The training course on post - harvest technologies on grain (combine harvester), Agriculture engineering research institute, department of agriculture, Chatuchak, Bangkok.

Manjit Singh, 1998, Improved post-harvest technology in Rice (Harvesting, threshing, drying and storage), ICAR research complex Manipur center, Imphal.

Pande, M.M. and Devnani, R.S., 1984, Development of improved sickles for harvesting cereals, AMA, Vol. 12(2), 54-58.

Veerangouda, M., Sushilendra, Prakash, K.V. and Anantachar, M., 2010, Performance evaluation of tractor operated combine harvester, Karnataka Journal of Agriculture Sciences, 23 (2), 282-285.

India Statistics, 2010-11, www.indiastat.com.

\section{How to cite this article:}

Ramappa, K.T., H. Sharanagouda, R. Udhayakumar and Devadattam, D.S.K. 2019. Estimation of Rice Losses while Harvesting the Crop by Manual Method and by Using Propeller Type Small Combine Harvester. Int.J.Curr.Microbiol.App.Sci. 8(08): 952-963. doi: https://doi.org/10.20546/ijcmas.2019.808.111 